\title{
Anatomoradiological Identification of Intrasutural Bones for Importance of Cranial Fracture
}

\author{
Kafa Kemik Kırıları Önemi Açısından Sütüral Kemiklerin \\ Radyoanatomik Olarak Saptanmast
}

\author{
Figen GOVSA ${ }^{1}$, Mehmet Asim OZER ${ }^{1}$, Selen BAYRAKTAROGLU², Ekin Ozgur AKTAS ${ }^{3}$ \\ ${ }^{1}$ Ege University, School of Medicine, Departments of Anatomy, Izmir, Turkey \\ ${ }^{2}$ Ege University, School of Medicine, Departments of Radiology, Izmir, Turkey \\ ${ }^{3}$ Ege University, School of Medicine, Departments of Forensic Medicine, Izmir, Turkey
}

Corresponding Author: Figen GOVSA / E-mail: figen.govsa@ege.edu.tr, fgovsa@yahoo.com

\begin{abstract}
AIM: Intrasutural bones are often found within sutures and fontanelles of the skull. It is important that the anatomy of these bones in the field of non-accidental injury with respect to medicolegal complications. Skull fracture lines are critical in their differential diagnosis, and the features of bone formations, their appearance and position give us a more definitive diagnosis.

MATERIAL and METHODS: Intrasutural bone location, its number and symmetry were investigated in totally 300 adult skulls.

RESULTS: 27 intrasutural bones were identified as interparietal (2\%), preinterparietal (3\%) and sutural bones (4\%) were in the lambdoid sutures. It was detected that the interparietal and preparietal bones were single, and the sutural ones were in a multiple number. The sutural bones were superposed in significant structures such as sagittal sinus and sinus sigmoideus.

CONCLUSION: The ones that should be paid attention to in the differential diagnosis of the skull fracture lines are preinterparietal and interparietal bones in larger sizes. These findings prompted us to report these cases as their presence can lead to confusion in diagnosis in cases of skull fractures.
\end{abstract}

KEYWORDS: Intrasutural bone, CT, Interparietal bone, Cranial fracture, Occipital bone, Wormian bone

öz

AMAÇ: Sütüral kemikler kafatasında sıklıkla sütürler ve fontaneller içinde yerleşmişlerdir. Bu kemiklerin anatomisinin önemi travmaya bağlı olmaksızın bulunması nedeniyle adli yansımalarıdır. Kemik kırık hatları ayırıcı tanı, kemik oluşumları, görünüm ve konumları bize daha kesin bilgi vermek açısından önemlidir.

YÖNTEM ve GEREÇLER: Sütüral kemiklerin yerleşimi, sayısı ve simetrisi 300 yetişkin kafatasında araştırıldı.

BULGULAR: 27 tane sütüral kemik tanımlandı: interparietal (\%2), preinterparietal (\%3) ve sütüral kemik (\%4) tanımıyla lambdoid sütür kemiği. Interparietal ve preparietal kemikler tek, sütüral olanları ise çok sayıda idi. Sütüral kemikler aynı zamanda sagittal sinüs ve sigmoid sinüs gibi önemli yapıların üzerine yerleşmiş idi.

SONUÇ: Preparietal ve interparietal kemiklerin daha büyük boyutlarda olması kırık hattı ayırıcı tanısında dikkat edilmelidir. Bu olgularda elde ettiğimiz kemiklerin, tanıda kafa kırıkları ile karışabileceği yönündedir.

ANAHTAR SÖZCÜKLER: Sütüral kemik, BT, İnterparietal kemik, Kafa kırıkları, Artkafa kemiği, Wormian kemik

\section{INTRODUCTION}

Intrasutural bones are small bones that are often found within the sutures and fontanelles of the skull. These bones are more commonly seen in patients with certain kinds of bone dysplasia such as cleidocranial dysostosis, pycnodysostosis, congenital hypothyroidism, rickets, but above all osteogenesis imperfect, which is the main differential diagnosis from abuse.

Majority of the researches concerning the variable intrasutural bones are conducted by radiologists and anatomists $(6,7$, $9-11,18,19,20,28-30)$. They are mainly based on the classical theories of embryogenesis of the occipital element $(2,13-15$,
$17,20,23,24,26)$. Despite the generally accepted conviction that the head shape is determined by the cranial sutures while the size is determined by the brain growth, the exact mechanisms have not been clearly explained yet (2). The role of the cranial sutures is to serve as bone growth sites which permit the extension of the face and the expansion of the braincase $(12,16,27)$.

Information obtained only as case report intrasutural bone is available related to the position and number of this. A variety of separated bones were also reported, i.e. Inca bones, wormian bones, preinterparietal bones and sutural bones, but these investigators did not rule out the difference among 
these bones in the lambda region. The differential diagnosis value of these bones in the clinic with respect to forensic cases is highly important. The anatomy of interparietal bones is important to know in the field of non-accidental injury in its medicolegal complications $(1,3,4)$. An important point for the neurosurgeon, radiologist, pediatrician, forensic pathologists is the skull fracture lines. Differential diagnosis of the fracture lines, crack and fissure intrasutural bone presentations that might be rendered in the bone tissues in the radiograms must be accomplished $(4,25)$. The features of these bones, their appearance and position give us a more definitive diagnosis. It is for the aim that search for intrasutural bones is an important step in the radiography investigations carried out for unexplained fractures in children and adults, in order to be able to clarify: is the person subject to physical abuse or do have brittle bones? The positions of the intrasutural bones, their number and their symmetry were investigated with the purpose of raising awareness in the differential diagnosis of the skull fracture lines which is an issue of great importance.

\section{MATERIALS and METHODS}

300 adult dry skulls of unknown age and sex obtained from the Turkish population were used to demonstrate the localization of the intrasutural bone. Our analysis are covered the presence, topography, and numbers of the intrasutural bones in sagittal suture, posterior fontanelle, posterolateral or mastoid fontanelle, and the right and left lambdoid sutures. These analyses were carried out on a post-treatment console using $3 D$ reconstructions with volume rendering. None of the specimens showed signs of bone malformation, prior cranial surgery or trauma. For these measurements, digital calipers sensitive to $0.01 \mathrm{~mm}$ have been used. Protractor and flexible metric where necessary, have been used for aspect measurements. Descriptive statistics (mean, minimum, maximum, standard deviation) were evaluated for all the parameters collected from skull measurements. Differences between the data of skull measurements were analyzed by the Student $t$ test.

All studies were conducted on a single tube DECT scanner with rapid kVp switching (Discovery HD750 HD' GE Health care). Examinations were performed with the following scan parameters: Tube voltage: $120 \mathrm{kVp}$ '. Tube current $600 \mathrm{~mA}$, rotation time $0,5 \mathrm{~s}$, collimation $64 \times 0,625 \mathrm{~mm}$. The image data sets were evaluated and processed on workstation. Volumerendered (VR) images were obtained.

The study was approved by a suitably constituted ethics committee of the institution within which the work was undertaken, and study conforms to the previous of the Declaration of Helsinki in 1964.

\section{RESULT}

In 27 out of the 300 skulls examined, single or multiple separated intrasutural bones were observed. According to their positions, these bones were classified into 3 types: interparietal, preinterparietal and sutural bones (Figures $1 \mathrm{~A}$ C, $2 \mathrm{~A}-\mathrm{C}, 3 \mathrm{~A}-\mathrm{C})$.
Preinterparietal bones were observed in 9 skulls (3\%), which included 6 instances of single bones and 3 of the multiple ones. They were mostly positioned at the central upper part of the interparietal squama; their base was higher than the midline between the lambda region and the highest line (Figure 1A). In 2 skulls, the preinterparietal bones were located in the posterior part of the sagittal suture; one of them was fused with the sagittal suture and one of them was fused with the interparietal squama. Figure $1 A$ and $B$ illustrate the presence of intrasutural bones in the sagittal and lambdoid suture as well as in the posterior fontanelle. The preinterparietals formed a triangular territory, while apparent sutural bones located around the region of the posterior fontanelle had an irregular arrangement and did not possess a triangular outline (Figure 1B).

Interparietal bones were single or multiple separated bones located within the sagittal suture. Their lower edges were usually situated slightly above the external occipital protuberance. Interparietal bones were observed in 6 skulls (2\%), which included 2 instances of single bones (Figure 1C) and 4 of the multiple ones. It was detected that the sides of the bones separating them from the parietal bone was highly jagged and rhomboid shaped.

Sutural bones situated along the right and left lambdoid suture. These bones were observed in 12 craniums (4\%). All of these craniums display bilateral sutural bone presence. They were observed as bones of miscellaneous dimensions, straight or jagged bordered, single, double, positioned sequentially or intermittently distorting the lambdoid suture line. Types of some of these were seen to be jagged bordered, indented structured (Figure 3A) or in the form of a straight line (Figure $3 C$ ). Single sutural bones were detected in a case. It was observed that the multiple sutural bones were arranged side by side in a sequence in a manner deteriorating the sutures line in lambdoidal (Figure 3B), as well as displaying an intermittent position in the suture (Figure $3 C$ ). The sutural bones were very small (Figure $3 C$ ), round (Figure $2 B$ ), rectangular (Figure $3 \mathrm{~B}$ ), stamp-shaped (Figure $2 \mathrm{C}$ ), triangular, rhombic or heart-shaped (Figure $2 \mathrm{~A}$ ) or elongated (Figure $3 \mathrm{~A}$ ) in shape. They did not exhibit any regular arrangement, or form a triangular territory.

It was also demonstrated that the sutural bones were located in significant structures such as sagittal sinus (Figure 4A), and sinus sigmoideus (Figure 4B), and that they were superposed. $3 \mathrm{D}$ image of the cranium were demonstrated sutural bones in the lambdoid suture (Figure 5A). In axial CT images, multiple sutures and intrasutural bones were noted in posterolateral fontanels (Figure 5B-F).

\section{DISCUSSION}

There have been many investigations on the anomalies, especially on the so-called separated interparietal bones as Inca bones $(19,23,24)$. The connection between the presence of the sutural bones and the number of their ossification centers was explored. Furthermore, embryological studies 


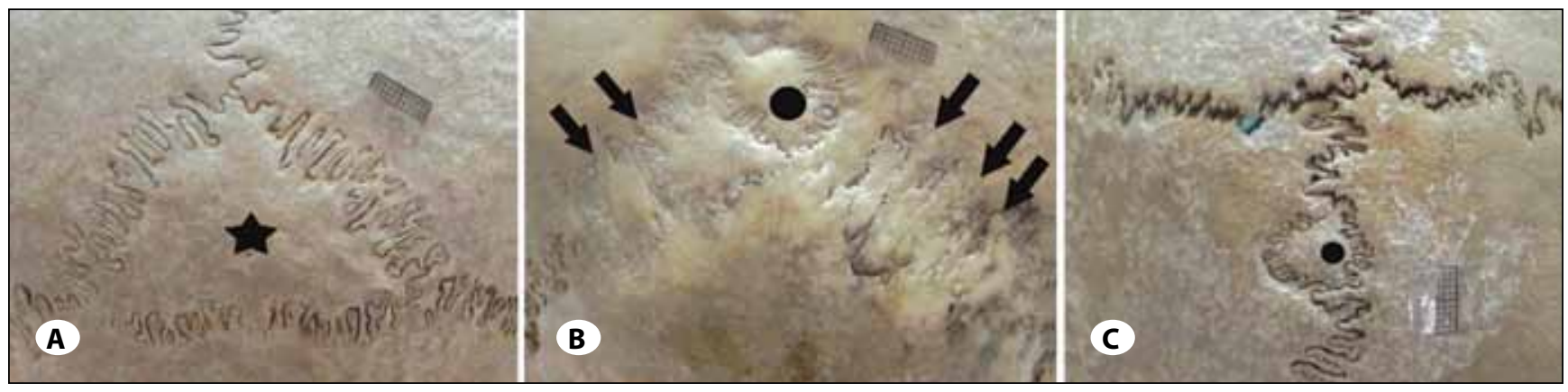

Figure 1: The different typology wormian bones in the posterior fontanelle. A) single preinterparietal, B) both preinterparietal and multiple sutural bones, $\mathbf{C}$ ) interparietal bone.

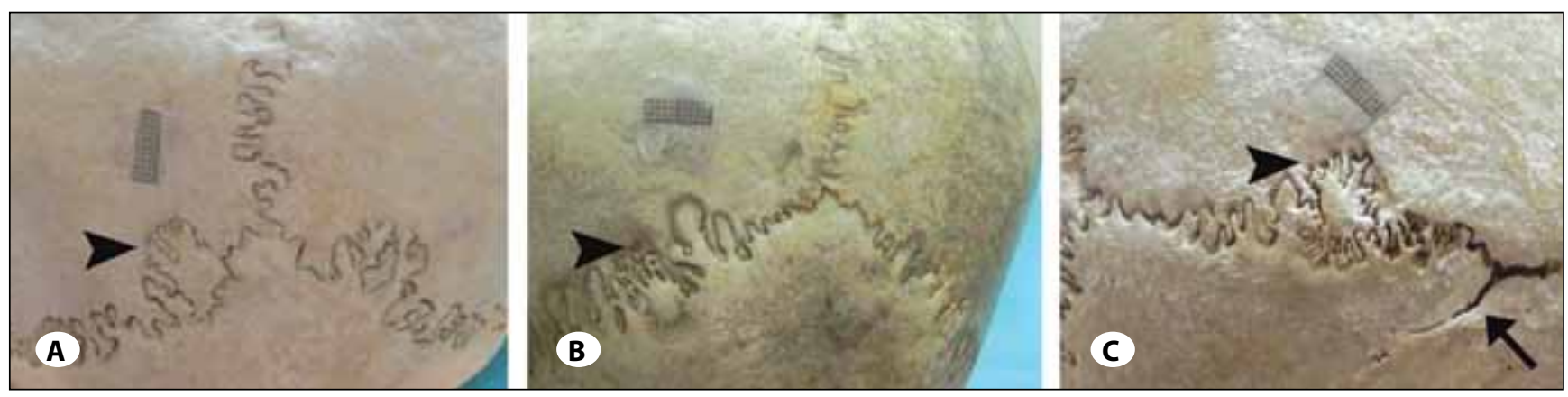

Figure 2: Examples of sutural bones in lambdoid suture $\mathbf{A}$ ) heart shaped, B) round, C) stamp shaped.

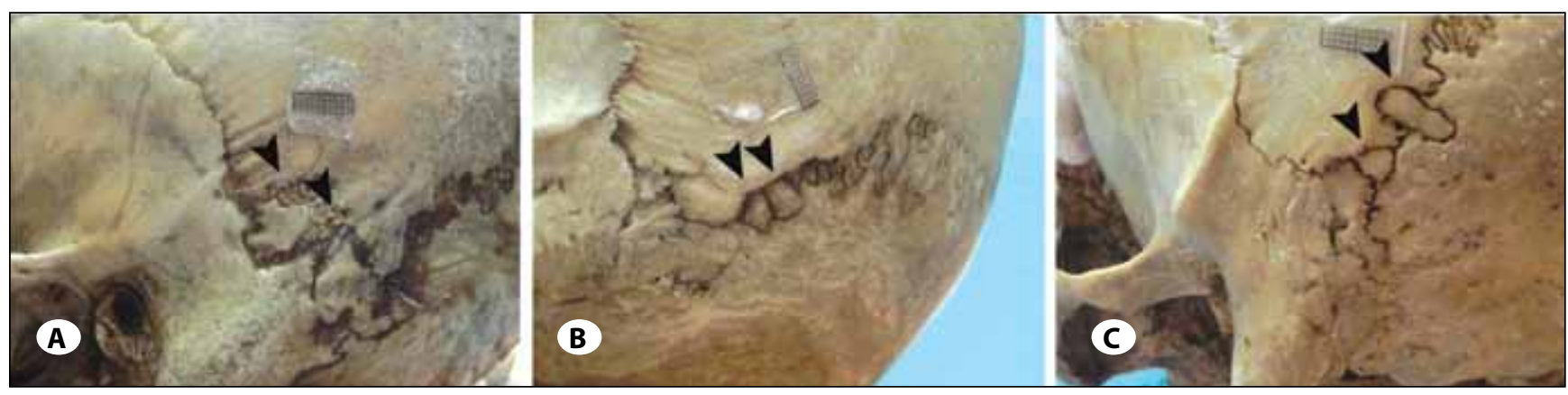

Figure 3: Multiple sutural bones in lambdoid suture. A) sides jagged, B) side by side, C) intermittent.
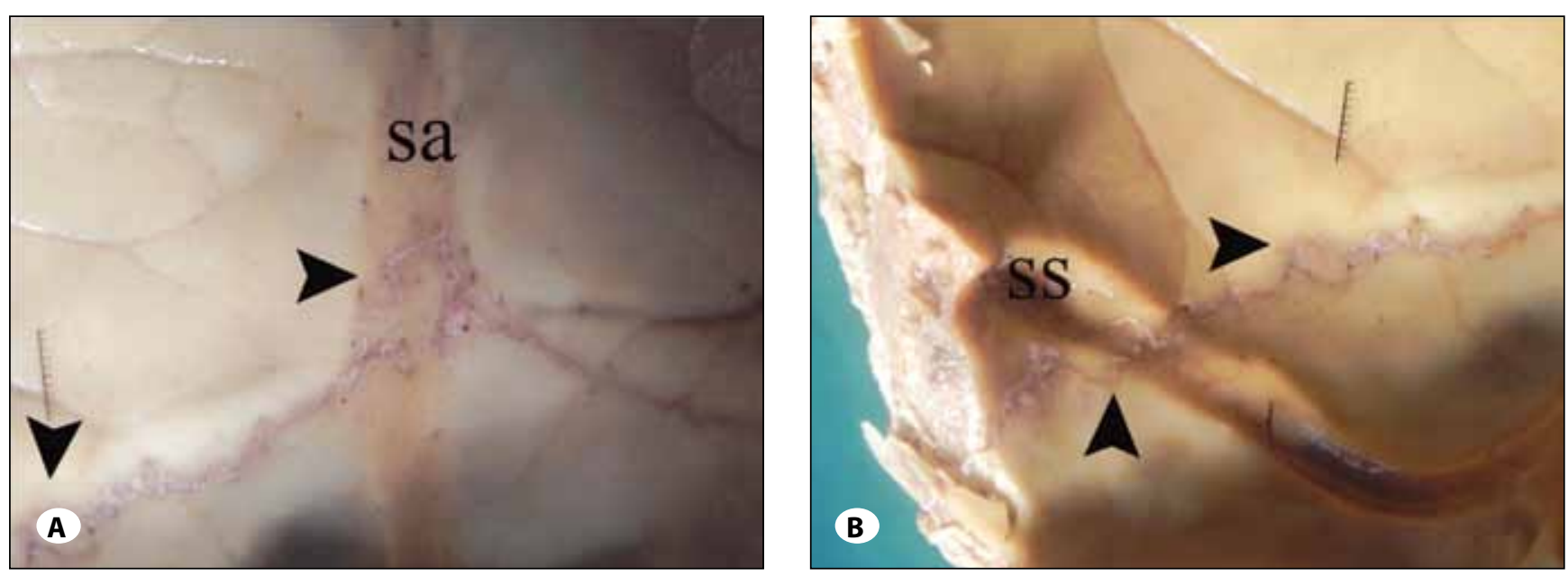

Figure 4: The close neighborhood of the sutural bones to the structures in the cerebral flow. A) the neighborhood of the interparietal bone to sagittal sinus (sa). B) the close neighborhood of the sutural bone to sigmoid sinus (ss). 

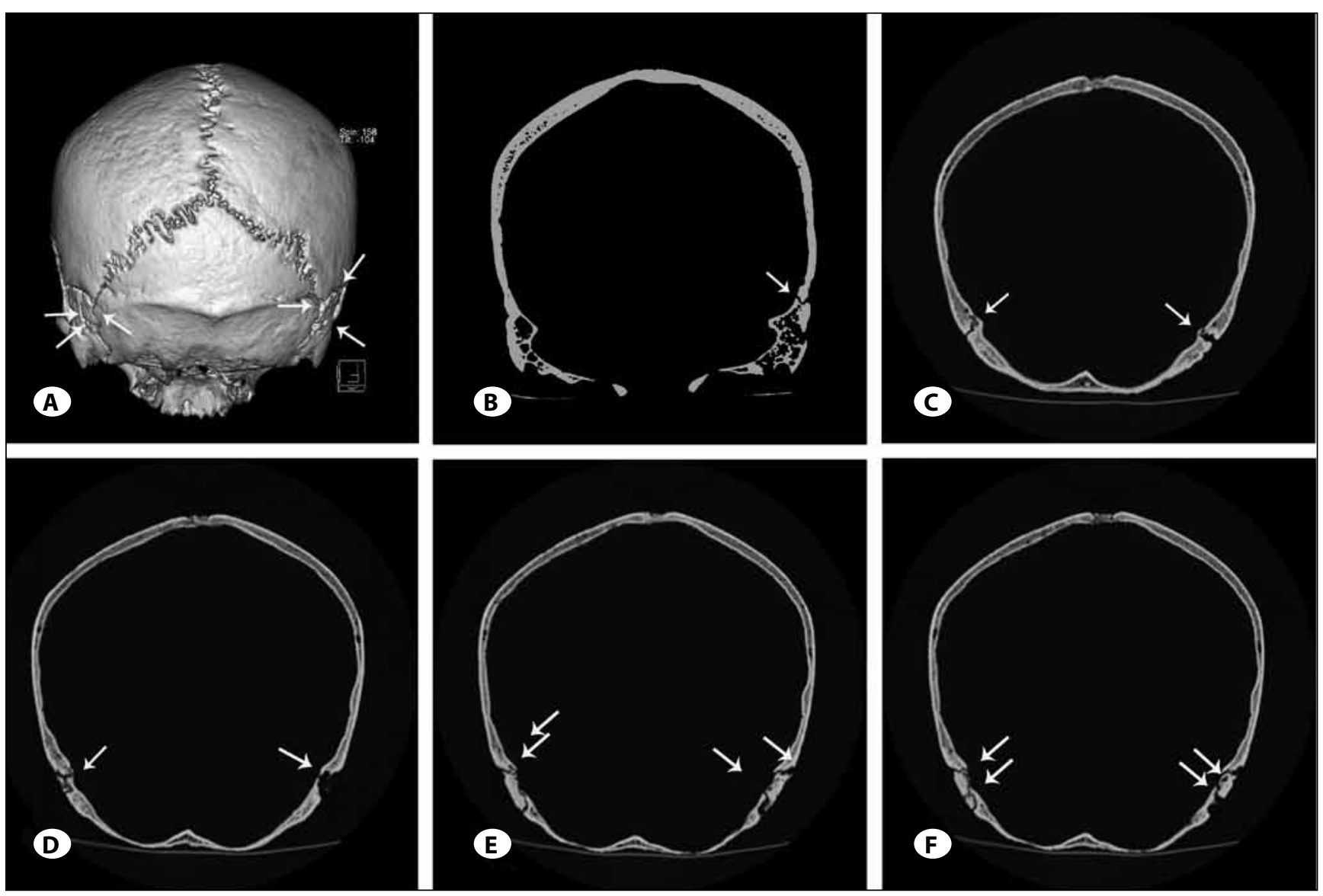

Figure 5: Images demonstrating anatomy: A) 3D-CT image of skull showing sutural bones (arrows) bilaterally, coronal CT image demonstrating suture (arrow) unilaterally in B) bilaterally in C) second sutures separate multiple intersutural bones in D-F) These sutures may be mistaken for a depressed fracture.

indicate that under normal circumstances, four occipital ossification centers fuse in a rapid manner during the fetal period and the suture lines are removed $(11,21,23,27)$. The formation of the Inca bones is caused by failure of fusion of the next interparietal bones. Moreover, one or more additional centers for the preinterparietal bone may appear around the lambda after the second interparietal bones are formed.

\section{Localization}

Despite the fact that the variations in appearance shapes of the sutural bones and its incidence have been recognized in previous radiological and anatomical studies, it has been observed that the pattern of intrasutural bone was not as simple as had been reported many authors $(6,7,11,10,18$, $19,21,22,28-30)$. However, in adult skulls, the location of the preinterparietal bones is different; they are found at the lambda. Their bases are higher than the midline between the highest nuchal line and the region of the lambda. On the other hand, researchers observed both fetal preinterparietal centers located anterior to the interparietal region and the adult skulls where the preinterparietal bones are found in the posterior part of the sagittal suture $(13,14)$. Thus, it is implied that preinterparietal centers with different locations could form different preinterparietal bones $(13,14,23,24)$. Based on this finding, these bones were classified into 3 types: interparietal, preinterparietal and sutural bones. Interparietal bones were positioned at the interparietal territory of the occipital squama. Preinterparietal bones were located the central upper part of the interparietal squama. Sutural bones situated along the lambdoid suture either neighboring the temporoccipital or the occipitoparietal.

\section{Types}

While most of studies were just case presentations only a few consisted of comprehensive details $(5,7,11,14,19)$. Previous studies were showed symmetrical bipartite, tripartite and multipartite examples. In the present study, we found various types of osseal variations in the interparietal region. The most common type of Os Incae is a single large triangular bone separated from the rest of the preinterparietal bone by a transverse suture. Less commonly, rhombic or heart-shaped forms may be seen $(6,18,22)$.

In our study the interparietal bones were stamp-shaped or rhomboid; the preinterparietal ones were triangular, and the sutural bones were round or heart-shaped drew attention. 
It was detected that the interparietal and preparietal bones were single, and the sutural ones were in a multiple number.

\section{Incidence}

In the studies conducted by several researchers in the large numbered bone collection, the prevalence of the sutural bones was reported as 0.4 - 2\% for interparietal bones, 0.5 $3 \%$ for preinterparietal bone, and 0.5 - $1 \%$ for sutural bones $(18,19,22,29,30)$. In our study, the prevalence was detected to be $2 \%$ for the interparietal bone, $3 \%$ for the preinterparietal bone, and $4 \%$ for the sutural bones.

\section{Significance of the Presence of Intrasutural Bones}

The awareness of anatomical variations in medicine is very important in many aspects. In forensic medicine it has also importance $(1,3,4,25)$. The variation might be person spesific so that it might be a fingerprint. Sometimes this awareness will save someone not to be called guilty. The variants of occipital bone, interparietal bones, preinterparietal bones or sutural bones might be mixed with fissured fractures $(1,3,4$, 25).

In our study; the sutural bones were detected to be generally in close neighborhood to lambdoid suture and sagittal suture. Additional ossificatory centers may occur in or near sutures, giving rise to isolated sutural bones. Usually irregular in size and shape, and most frequently in the lambdoid suture, they sometimes occur at fontanelles, especially the posterior. Some authors did not evaluate the concept of sutural bones, and certain authors examined all bones in the scope of Inca bones. Of the bones observed in our study, the ones near the location of the center of the classified sagittal suture were identified as interparietal, and the ones nearby the lambda as preinterparietal. The ones on the lambdoid suture were identified as sutural bones. The fact that the interparietal located ones were rather stamp-shaped or rhomboid; the preinterparietal ones were triangular and, the sutural bones were round or heart-shaped attracted attention. It has been determined that the interparietal and preparietal bones were single, and the sutural ones were in a multiple number in the cranium. It was also demonstrated that the sutural bones were settled in significant structures such as sagittal sinus (Figure 4A), and sinus sigmoideus (Figure 4B), and that they were superposed. This is meaningful in terms of putting forward the value of differential diagnosis.

Recently, skull factures have been associated by the researchers with higher risks in intracranial lesion, neurological deficit and poorer outcomes (3). Fractures are sharp and transparent and largely straight or jagged. They may cross sutures. Other phenomena associated with fractures are also the overlying scalp hematoma or extraaxial hemorrhage. An osseal suture that is sigmoidal and has sclerotic margins will be identified in normal anatomical locations. However, sutural interdigitations are not available on the inner table and they are considerably smooth. The straight structure of the suture may be confused with the fracture in some cases (1). In the case of a diastatic suture from fracture, the suture is widened for more than $2 \mathrm{~mm}$ by a fracture seemingly extending into the suture. Findings obtained through skull X-ray are limited and thus, existence of a linear skull fracture alone does not cause a change in the patient management (4).

To be able to distinguish a fracture from a suture, one should be aware of the appearance and position of the normal sutures and the variants $(5,15)$. MRI does not show sutures clearly and CT may also fail to distinguish a suture from a fracture if there is only the axial image $(5,6,8,12,21)$. It was advised that, in case occipital bone injuries the treating clinician should plan a meticulous differential diagnosis and should go for a 3D-CT scan especially in patients with low Glasgow coma score. The reconstructed 3D-CT scan may provide informative value in comparison to the conventional radiographs in the diagnostic sequence of traumatized patients. The information about variant sutures is enlightening for the medicolegal consultants and forensic experts.

Both of there are no abnormal findings on neurologic examination and no swelling or soreness in the occipital area. Based on the absence of swelling or soreness in the occipital region, bone defects were not fracture lines but unusual cranial sutures. There are no clear points of differentiation between fracture lines and suture lines observed in the skull and the differential diagnosis may be difficult, especially if linear defects are present within the occipital bone. Complex development patterns in this site may result in several residual linear defects simulating fractures. Incomplete embryological knowledge of the bones in this region might have a major effect on explanations given to families in the course of observation of patients. The bone defects based on intrasutural bones were probably cranial suture lines because there was no evidence of soreness or swelling in the occipital area, the linear bone defects had a symmetrical distribution; there was no past history of head injury, and the known occurrence of unusual rich accessory sutures and ossicles around the foramen magnum (Figure 5C-F). The location of the linear bone defects in the present case appeared similar to that described earlier for lateral fissures.

The medical-legal problems implied lie in the definition of the exact manner and cause of death, and therefore in the analysis of vital, perimortal injuries, as to formulate a differential diagnosis between the former trauma originated and caused by combustion. The presence of this variation may be occasionally useful in the identification of an unknown or lost person. This is of particular significance in the cases, for example, of murder or child abuse.

\section{CONCLUSIONS}

The present study indicates intrasutural bone may be present most frequently in the lambdoid suture. It is important for neurosurgeons and radiologists to be aware of the presence sutural bone as they may be mistaken for fractures in cases of head injuries. Therefore, this research may be useful neurosurgeons, radiologist, and antropologists. 


\section{REFERENCES}

1. Allen WE 3rd, Kier EL, Rothman SL: Pitfalls in the evaluation of skull trauma. A review. Radiol Clin North Am 11(3):479-503, 1973

2. Bristol RE, Krieger MD, McComb JG: Normally shaped heads with no sutures, normally shaped heads with abnormal sutures, and abnormally shaped heads with normal sutures. J Craniofac Surg 22(1):173-177, 2011

3. Bullock MR, Chesnut R, Ghajar J, Gordon D, Hartl R, Newell DW, Servadei F, Walters BC, Wilberger J: Surgical management of depressed cranial fractures. Neurosurgery 58(3 Suppl):S56-S60, 2006

4. Castillo $\mathrm{M}$, Harris $\mathrm{JH}$ : Imaging of skull and brain emergencies. In: Harris JH, Harris WH (eds.) The Radiology Of Emergency Medicine, 4th ed. Philadelphia 2000:1-48

5. Furuya $Y$, Edwards MS, Alpers CE, Tress BM, Norman D, Ousterhout DK: Computerized tomography of cranial sutures. Part 2. Abnormalities of sutures and skull deformity in craniosynostosis. J Neurosurg 61(1):59-70, 1984

6. Choudhary AK, Jha B, Boal DK, Dias M: Occipital sutures and its variations: The value of $3 \mathrm{D}-\mathrm{CT}$ and how to differentiate it from fractures using 3D-CT? Surg Radiol Anat 32(9):807-816, 2010

7. Fujita MQ, Taniguchi M, Zhu BL, Quan L, Ishida K, Oritani S, Kano T, Kamikodai Y, Maeda H: Inca bone in forensic autopsy: A report of two cases with a review of the literature. Leg Med (Tokyo) 4(3):197-201, 2002

8. Glass RB, Fernbach SK, Norton KI, Norton KI, Choi PS, Naidich TP: The infant skull: A vault of information. Radiographics 24(2):507-522, 2004

9. Gayretli O, Gurses IA, Kale A, Aksu F, Ozturk A, Bayraktar B, Sahinoglu K: The mendosal suture. Brit J Neurosurg 25(6): 730-733, 2011

10. O'Loughlin VD: Effects of different kinds of cranial deformation on the incidence of wormian bones. Am J Phys Anthropol 123:146-155, 2004

11. Malhotra VK, Tewari PS, Pandey SN, Tewara SP: Interparietal bone. Acta Anat (Basel) 101:94-96, 1978

12. Mann SS, Naidich TP, Towbin RB, Doundoulakis SH: Imaging of the postnatal maturation of the skull base. Neuroimag Clin $\mathrm{N}$ Am 10(1):1-219, 2000

13. Matsumura G, Uchiumi T, Kida K, Ichikawa R, Kodama G: Developmental studies on the interparietal part of the human occipital squama. J Anat 182:197-204, 1993
14. Matsumura G, England MA, Uchiumi T, Kodama G: The fusion of ossification centres in the cartilaginous and membranous parts of the occipital squama in human fetuses. J Anat 185:295-300, 1994

15. Nikolić S, Zivkovic V, Juković F: Interparietal bone in forensic practice: Case report. Srp Arh Celok Lek 138(11-12):764-767, 2010

16. Opperman LA: Cranial sutures as intramembranous bone growth sites. Dev Dyn 219(4):472-485, 2000

17. Pal GP, Tamankar BP, Routal RV, Bhagwat SS: The ossification of the membranous part of the squamous occipital bone in man. J Anat 138:259-266, 1984

18. Pal GP: Variations of the interparietal bone in man. J Anat 152:205-208, 1987

19. Saxena SK, Chowdhary DS, Jain SP: Interparietal bones in Nigerian skulls. J Anat 144:235-237, 1986

20. Shapiro R, Robinson F: Embryogenesis of the human occipital bone. Am J Roentgenol 126: 1063-1068, 1976

21. Shapiro R, Robinson F: The Os Incae. Am J Roentgenol 127:469-471, 1976

22. Singh PJ, Gupta CD, Arora AK: Incidence of interparietal bones in adult skulls of agra region. Anat Anz 145:528-531, 1979

23. Srivastava HC: Development of ossification centres in the squamous portion of the occipital bone in man. J Anat 124(Pt 3):643-649, 1977

24. Srivastava HC: Ossification of the membranous portion of the squamous part of the occipital bone in man. J Anat $180(\mathrm{Pt}$ 2):219-224, 1992

25. Tharp AM, Jason DR: Anomalous parietal suture mimicking skull fracture. Am J Forensic Med Pathol 30(1):49-51, 2009

26. Tubbs RS, Salter EG, Oakes WJ: Does the mendosal suture exist in the adult? Clin Anat 20(2):124-125, 2007

27. Warren SM, Greenwald J, Spector JA, Bouletreau P, Mehrara BJ, Longaker MT: New developments in cranial suture research. Plast Reconstr Surg 107:523-540, 2001

28. Wu JK, Goodrich JT, Amadi CC, Miller T, Mulliken JB, Shanske AL: Interparietal bone (Os Incae) in craniosynostosis. Am J Med Genet A 155A(2):287-294, 2011

29. Yucel F, Egilmez H, Akgun Z: A study on the interparietal bone in man. Tr J of Med Sci 28(5):505-509, 1998

30. Zambare BJ: Incidence of interparietal bones in adult skulls. J Anat Soc India 50:11-12, 2001 